\title{
Psychometric properties of the Spanish version of the Exercise Imagery Questionnaire (EIQ)
}

\section{Propiedades psicométricas de la versión en español del Exercise Imagery Questionnaire (EIQ)}

\section{Propriedades psicométricas da versão em espanhol do Exercise Imagery Questionnaire (EIQ)}

\author{
Pérez-Fabello, M. J.1 \& Campos, A.2 \\ ${ }_{1}$ University of Vigo; 2 University of Santiago de Compostela
}

\begin{abstract}
In this study, the psychometric properties of the Spanish version of the Exercise Imagery Questionnaire (EIQ) were evaluated in a sample of 166 first-year undergraduates of a Bachelor's degree in Physical Activity and Sports Sciences, 127 men, and 39 woman; Mage $=20.57, S D=2.24$. Participants exercised at least 4 times a week. Moreover, the Spanish versions of four mental imagery questionnaires were administered: MIQ-R, VMIQ, VVIQ, and Gordon Test. Two confirmatory factor analyses of the EIQ were performed. First, a three-factor model (technique, energy, and appearance imagery) the same as the original model, failed to obtain the recommended values for a good fit. However, the second model adjusted to two factors (technique and energy imagery) was good (CFI $=.97, \mathrm{NNFI}=.94, \mathrm{RMSEA}=.07, \mathrm{SRMR}=.04)$ with results similar to the original test. Reliability was acceptable as measured by the Cronbach's alpha, but composite reliability was lower than recommended. However, convergent and discriminant validity was inadequate. There was a significant correlation between the EIQ and the Gordon Test. Furthermore, Tables have been included as an aid the elucidation of the results of the sample of undergraduates on the Bachelor's degree in Physical Activity and Sports Sciences. The results are discussed, and substantiated the Spanish version of the EIQ was a valid and useful test for exploring two types of imagery in particular: technique and energy.
\end{abstract}

Keywords: visualitation; reliability; validity; physical activity.

\section{RESUMEN}

En este studio se evaluaron las propiedades psicométricas de la versión en español del Cuestionario de Imágenes de Ejercicio (EIQ) en un grupo de 166 ( 127 hombres y 39 mujeres ) estudiantes de de primer año de grado en Ciencias de la Actividad Física y del Deporte $(M e d a d=20.57, S D=2,24)$. Los participantes realizaban ejercicio al menos 4 veces por semana. Además administramos la version Española de cuatro cuestionarios de imagen mental: MIQ-R,

Correspondence to: María José, Pérez-Fabello. Dirección Postal: Facultad de Bellas Artes, Rúa Maestranza, 2, 36002, Pontevedra, Spain Tel: 34986801 879. Email: fabello@uvigo.es 


\section{Pérez-Fabello, María José \& Campos, Alfredo}

VMIQ, VVIQ, Gordon Test. Llevamos a cabo dos análisis confirmatorios del EIQ, en primer lugar, un modelo con tres factores (imagen de técnica, energía y apariencia) similar al original, aunque no cumplía los valores recomendados para un buen ajuste. Sin embargo, el ajuste del segundo modelo con dos factores (imagen de técnica y energía) fue bueno $(\mathrm{CFI}=.97, \mathrm{NNFI}=.94, \mathrm{RMSEA}=.07, \mathrm{SRMR}=.04)$, con resultados similares a la prueba original. La fiabilidad medida a través del alfa de Cronbach fue acceptable pero la fiabilidad compuesta fue más baja de lo recommendable. La validez convergente y discriminate resultó adecuada. Encontramos una correlación significativa entre el EIQtécnica y el Gordon Test. También se incluyó una tabla de baremación del grupo estudiantes of Physical Activity and Sports Sciences. Los resultados se discutieron, y se observó que la version Española del EIQ es una prueba válida y útil para explorar, especialmente, dos tipos de imagen: técnica y energía.

Palabras clave: visualización; fiabilidad; validez; actividad física.

\section{RESUMO}

Neste estudo avaliamos as propriedades psicométricas da versão em espanhol do Exercise Image Questionnaire (EIQ). Participaram 166 (127 homens e 39 mulheres) alunos do primeiro ano de uma licenciatura em Atividade Física e Ciências do Desporto (Midade $=20.57, S D=2,24$ ). Os participantes exercitaram-se pelo menos 4 vezes por semana. Além disso, administramos a versão em espanhol de quatro questionários de imagem mental: MIQ-R, VMIQ, VVIQ, Gordon Test. Foram realizadas duas análises confirmatórias do EIQ, primeiro um modelo com três fatores (imagem técnica, energia e aparência), exatamente como o original, embora não se atendesse aos valores recomendados para um bom ajuste. No entanto, o ajuste do segundo modelo com dois fatores (técnica e imagem energética) foi bom $(\mathrm{CFI}=.97, \mathrm{NNFI}=.94, \mathrm{RMSEA}=.07, \mathrm{SRMR}=.04)$ com resultados semelhantes ao teste original. A confiabilidade medida através do alfa de Cronbach foi aceitável, mas a confiabilidade composta foi menor que o recomendado. A validade convergente e discriminada foi adequada. Houve uma correlação significativa entre o EIQtécnica e o teste de Gordon. Também foi incluída uma tabela de escala do grupo de estudantes de Atividade Física e Ciências do Desporto. Os resultados foram discutidos, e observou-se que o EIQ é um teste válido e útil para explorar, principalmente, dois tipos de imagem: técnica e energia.

Palavras chave: visualização; confiabilidade; validade; actividade física.

\section{INTRODUCTION}

Mental imagery is an effective technique that has been used in many different types of physical and sports activities (Cumming \& Ramsey, 2009; Giacobbi, Hausenblas, \& Penfield, 2005; Kossert \& MunroeChandler, 2007). Using mental imagery involves recreating an experience stored in the memory or creating a new one for the purpose of improving learning, and developing certain skills aimed at performance optimization (Simons, 2000). As a mental technique used in the sports context, it is also employed to enhance self-confidence, to control excitement and anxiety, and raise motivation and goal achievement in sportspeople (Cumming \& Williams, 2012; Palmi Guerrero and Riera Riera, 2016). The current interest in mental imagery in fields such as sports and physical training has been well illustrated by several studies such as Campos, López-Araujo, and
Pérez-Fabello's (2016) analysis of the types of mental imagery used in physical and sports activities. A wide range of sports have been found to benefit from using mental imagery visualization training techniques such as basketball (Rekik, Khacharem, Belkhir, Bali, \& Jarraya, 2019); football, both in player (PerisDelcampo, 2019), and team studies (MorenoFernández et al., 2019); golf (Frank, Land, Popp, \& Schack, 2014, 2016), tennis (Fortes et al., 2019, Meier, Frank, Gröben, \& Schack, 2020 ), and volleyball (Fortes et al., 2020).

Studies on imagery movement have primarily focused on one specific type of imagery, motor imagery. Motor imagery is a dynamic mental representation enabling a motor movement to be exercised in the working memory, without performing the action in reality (Decety, 1996). The practice of motor imagery, which 


\section{Spanish version of the EIQ}

is widely popular and has been researched extensively, is a mental simulation process, also known as mental practice, involving the systematic use of imagery to exercise a movement without performing the action itself (Di Rienzo et al., 2016). Recent studies have used physiological measures for assessing mental practice. Lebon et al. (2019) evaluated motor imagery and its involvement in the processes of preparation and real-life execution of movements using transcranial magnetic stimulation. A recent study using physiological tests, Zabicki et al. (2019), observed spatial patterns of neuronal activity in imagined actions measured by fMRI scanning, and significant positive correlations between neuronal neural dissimilarity values and the participants' subjective evaluations of the intensity of image vividness. Moran and O'Shea (2020) suggests that the practice of motor imagery drives relatively high levels of the motor system that refine and perfect the mental representations of an athlete's actions during the first stages of skills acquisition.

Numerous studies on motor imagery have been underpinned by the motor simulation theory (for further information see: Moran \& O'Shea, 2020; Moreno-Fernández et al., 2019; Peris-Delcampo, 2019). This theory asserts mental practice is efficacious as an imagined movement involves the internal simulation of the real movement in designing an action plan, predicting the outcome, and in preparing the means to achieve the goals. Moreover, there is a functional equivalence between simulation and executing an action. This theory draws on the taxonomy of Paivio (1985), subsequently extended by other authors (see, Munroe-Chandler, \& Gammage, 2005), who have proposed five imagery functions: Cognitive Specific (e.g., skills), Cognitive General (e.g., strategies), Motivational Specific (e.g., setting objectives), General Motivational-Anxiety (e.g., excitation), and General Motivation -Dominio (e.g., self-confidence). Both simulation theory and Paivio's (1985) taxonomy underpin the studies of Hall (1995), who was one of the first authors to point out the benefits of imagery in sports, both in competitive and recreational, and link exercise and physical activity. Moreover, Hall suggested that exercise imagery enhanced self-confidence for task performance by providing people with a sense of achievable success. Hall's findings paved the way for new research on exercise imagery, giving rise to the Exercise Imagery
Questionnaire (EIQ; Hausenblas, Hall, Rodgers, \& Munroe, 1999). Though this measurement instrument was designed on the premise that imagery has cognitive and motivational functions, the questionnaire does not covered the entire range of imagery functions (for a review of the model see, Munroe-Chandler, \& Gammage, 2005). Participants in the Hausenblas et al.'s study (1999) were volunteer aerobic practitioners who belonged two different university campuses (144 undergraduates $89 \%$ women in the first campus, and 267 undergraduates, 97.6\% women in the second). The items on the test were drawn from the first phase of the study following the participants' response to three basic questions: When do exercisers use imagery? Why do exercisers use imagery? and What do exercisers image? Content validity was determined by six experts (three exercise professionals and three exercise participants).

After a confirmatory factor analysis, Hausenblas et al. (1999) found three factors corresponding to three types of imagery commonly used by users: (i) appearance imagery, which refers to imagining oneself becoming healthier and improving one's physical appearance; (ii) energy imagery, which is related to imagining oneself full of energy and ready to exercise; and (iii) technique imagery, which implies imagining the correct execution of the technique. The analysis of the fit indexes indicated excellent model fit $(\mathrm{RMSEA}=.05 ; \mathrm{AGFI}=.93 ; \mathrm{CFI}=.97)$. Cronbach's alphas for the subscales were acceptable ( $\alpha$ from .71 to .85). Finally, Hausenblas et al.'s (1999) study found most participants regularly exercising used imagery at different times and situations, and that the use of mental imagery increased with exercise.

Gammage, Hall and Rodgers (2000) delved deeper into the study of exercise imagery by applying the EIQ to a sample of 577 exercisers (312 women) who participated in a wide variety of physical activities. The results showed that gender, exercise frequency, and the type of physical activity influenced the use of exercise imagery. Appearance imagery was used most often, followed by technique, and energy imagery, respectively. Gender also influenced the use of exercise imagery, with significant differences found between men and women in appearance, and technique imagery. Women used appearance imagery more often than men, but men used technique imagery more often than women. Moreover, each specific type 


\section{Pérez-Fabello, María José \& Campos, Alfredo}

of physical activity was found to determine preferences in the use of exercise imagery. Later several EIQ studies have corroborated the assertion that the frequency of exercise imagery positively predicts exercise behaviour and intention (for a review see Kossert \& Monroe-Chandler, 2007; MunroeChandler \& Gammage, 2005).

Gammage et al. (2000) have conjectured different types of exercise imagery influence motivation to exercise, and that images based on physical appearance play a vital motivational role in sportspeople. In a more detailed study on a sample of 150 active exercisers (193 women) engaged in an array of exercise activities, Stanley, Cumming, Standage, and Duda (2012) found that, despite being associated to motivation as pointed out by Gammage et al. (2000), appearance imagery was actually motivation controlled, in other words, it dealt with an external motivation focused primarily on physical improvement in sports. However, technique imagery was positively related to autonomous motivation (intrinsic motivation), which consisted of using images for a correct execution of an exercise. This approach reflects an intrinsic focus for the use of technique imagery as a psychological strategy.

Although Stanley et al. (2012) found no significant relation between energy imagery and autonomous motivation, these authors assumed the motivational role of this imagery would be transformed in time, being more intrinsically gratifying in the long term. Likewise, Munroe-Chandler and Gammage (2005) have suggested the nature of a user's imagery may vary throughout the process of exercising, initiatory images may involve results-based content (such as those related to appearance) in order to initially set the intention to exercise. Later on, during the training session, users may take a different approach using more energy images so as to keep their energy and excitement up. Hall, Rodgers, Wilson, and Norman's (2010), analysis of a sample of 470 participants (252 women), of whom 202 were regular exercisers, 138 non-exerciser who intended to exercise, and 130 nonexerciser with no intention of exercising. They found interventions with mental imagery were efficacious in regular exercisers, and non-regular exercisers, although intended on exercising, but the efficacy of mental imagery in non-exercisers with no intention of exercising was low.
Rodgers, Hall, Blanchard, and Munroe (2001) found images represented $20 \%$ of the variance in obligatory exercise using the EIQ before and after a 10-week exercise program of 243 adult exercisers. Appearancerelated images did not significantly predict obligatory exercise, and energy-related images were the strongest predictor. In a later study, Rogers, Munroe, and Hall (2002) found that appearance imagery significantly predicted exercise intention but failed to predict exercise behaviour.

Kossert and Munroe-Chandler's (2007) review concluded that exercise imagery could be an efficient tool for improving performance and adherence to physical activity programs. Ajibua and Peculiar (2016) confirmed this result on a sample of 150 undergraduates (81 women).

Bearing in mind that visualization of physical activity in non-competitive sport has received scarce attention in the scientific literature, IEQ can be considered a good general measure of the mental imagery of exercise. Thus, the aim of the present study was to translate the EIQ into Spanish and to assess the psychometric properties of the Spanish version of the Exercise Imagery Questionnaire (EIQ; Hausenblas et al., 1999). It was postulated that the Spanish version of the EIQ would have a similar number of factors as the English version (Hausenblas et al., 1999), with good validity and reliability. We also working with the hypothesis was there would be significant correlations between EIQ and four mental imagery tests translated into Spanish, the psychometric proprieties of which have been analysed in previous studies. Two of the movement imageries questionnaires applied in this study have been extensively used in physical and sports activities: The Spanish version (Campos \& González, 2010) of the Movement Imagery Questionnaire-Revised (MIQ-R; Hall \& Martin, 1997), and the Spanish version (Campos \& Pérez, 1990) of the Vividness of Movement Imagery Questionnaire (VMIQ; Isaac, Marks, \& Russell, 1986). The general imagery vividness test used was the Spanish version (Campos, González, \& Amor, 2002) of the Vividness of Visual Imagery Questionnaire (VVIQ; Marks, 1973), as well as the Spanish version of the mental imagery control test (Pérez-Fabello, \& Campos, 2004) of the Gordon Test of Visual Imagery Control (Gordon Test, Richardson, 1969). 


\section{Spanish version of the EIQ}

\section{MATERIAL AND METHOD}

\section{Participants}

The sample consisted of a total of 166 first-year undergraduates on the Bachelor's degree in Physical Activity and Sports Sciences at a Spanish state University, 127 men and 39 women; age range 18 to 26 years, mean age 20.57 years, $(S D=2.24)$. Participants were regular exercisers, exercising 4 times weekly, and practicing a broad range of sports: fitness, athletics, kayak, surf, tennis, sailing, rowing, swimming, football, rugby, and volleyball.

\section{Materials}

The Spanish translation of the Exercise Imagery Questionnaire (EIQ; Hausenblas et al., 1999). The EIQ consists of 9 items related to the frequency of use of mental images while exercising. Participants must value the frequency of images on a 9-point scale ( $1=$ never and $9=$ always). The questionnaire is composed of three subscales: technique, energy, and appearance. The technique subscale represents a cognitive function of images and is centred on execution skills and correctly executed techniques. For example, "When I think about exercising, I imagine my form and body position" is one item that assesses technique imagery. The energy subscale is believed to play a motivational role and linked to being excited or energetic while exercising. An example of an item is "To take my mind off work, I imagine exercising". The third subscale, appearance, is also related to a motivational function centred on fitness that includes items such as "I imagine a fitter-me from exercising". The data in the present study obtained a Cronbach's alpha of .78 for the three-factor EIQ total, and .70 for the twofactor EIQ total, as well as .78 for the technique scale, .75 for the energy scale, and .78 for the appearance scale. The Cronbach's alphas for the EIQ subscales were below the levels found in previous studies: Hausenblas et al., 1999: technique $=.86$, energy $=.90$, and appearance $=.84$; Rodgers et al., 1999: technique $=.90$, energy $=.88$, and appearance $=.87$; Gammage et al., 2000: technique $=.86$, energy $=.85$, and appearance $=.87$; Gammage, Hall, \& Ginis, 2004: technique $=.90$, energy $=.81$, and appearance $=.88$; Rogers et al., 2002: technique $=.83$, energy $=.87$, and appearance $=.78 ;$ Wilson, Rodgers, Hall, $\&$ Gammage, 2003: technique $=.85$, energy $=.87$, and appearance $=.88$; and Hall et al., 2010: ranging from .74 to .89 .
The Spanish version (Campos \& González, 2010) of the Movement Imagery Questionnaire-Revised (MIQR; Hall \& Martin, 1997). The test comprises 8 items, 4 on the visual scale and 4 on the kinaesthetic scale. Each item involves moving an arm, leg, or the whole body. It takes four steps to complete each item: first, a position for a movement is described and the participant is asked to carry it out. Secondly, a movement is described and the participant must perform it. Thirdly, the participant is asked to go back to the initial position and then to imagine her- or himself making the movement (of the items of the visual scale), or to feel the movement she or he has just made (in the items of the kinaesthetic scale) without actually making the movement. Finally, the participant is asked to evaluate the difficulty with which she or he imagined or felt the movement on a 1-7-scale, 1 being "very easy to imagine or feel" and 7 "very difficult to imagine or feel". In this study the Cronbach's alpha was .86 for the total scale, .84 for the visual subscale, and .92 for the kinesthetic subscale. Vadocz, Hall, and Moritz (1997) found a Cronbach's alpha of .79 for the visual scale, and .79 for the kinesthetic scale. Campos and González (2010) obtained a Cronbach's alpha of .84 for the total scale, .80 for the visual scale, and .84 for the kinesthetic scale. Additionally, the MIQ-R rendered a correlation of $-.34(p<.001)$ with the VMIQ, and $-.26(p<.001)$ with the VVIQ.

The Spanish version (Campos \& Pérez, 1990) of the Vividness of Movement Imagery Questionnaire (VMIQ; Isaac, Marks, \& Russell, 1986). The VMIQ consists of 24 items designed to assess the ability to visually and kinesthetically imagine an array of movements. When completing the VMIQ, participants are required to imagine and evaluate $(1=$ perfectly clear and as vivid as normal vision, and $5=$ no image, you only know that you are thinking of the skill) each item was evaluated twice: first, by imagining watching somebody else perform the movement, and second, by imagining performing the movement themselves. Thus, there are a total of 48 responses with low scores corresponding to more vivid imagery. The 24 items fall into six groups, with four items in each group. The groups are as follows: items relating to basic body movements (Items 1-4, for example, "Walking"); items relating to basic movements with more precision (Items 5-8, for example, "Reaching for something on tiptoe"); items relating to movement with control but some unplanned risk (Items 9-12, for example, 


\section{Pérez-Fabello, María José \& Campos, Alfredo}

"Falling forwards"); items relating to movement controlling an object (Items 13-16, for example, "Catching a ball with two hands"); items relating to movements that cause imbalance and recovery (Items 17-20, for example, "Running downhill"); and items relating to movements demanding control in aerial situations (Items 21-24, for example, "Jumping into water"). The Cronbach's alpha for the VMIQ was .98 for the questionnaire total, .97 for imagining oneself making the movement, and .97 imagining somebody else making the movement. VMIQ test-retest reliability has been demonstrated over a 3-week period with a group of physical education students, $r=.76$ (Isaac et al., 1986). The VMIQ has also demonstrated adequate concurrent validity with the Vividness of Visual Imagery Questionnaire with novice, experienced, and international-level trampolinists. The correlations were $.75, .45$, and .65 respectively (Isaac et al., 1986).

The Spanish version (Campos et al., 2002) of the Vividness of Visual Imagery Questionnaire (VVIQ; Marks, 1973) is composed of 16 items relating to different situations, for example, "Visualise a rising sun. Consider carefully the picture that comes before your mind's eye". Participants must visualise and evaluate the vividness of each given image, for instance, in the previous situation: "The sun is rising above the horizon into a hazy sky". Image vividness must be assessed on a 5-point scale, 5 meaning "no image, you only know what you are thinking of the skill", and 1 meaning "a perfectly clear image and as vivid as normal vision". Thus, high scores in the VVIQ indicate low image vividness. Participants complete the questionnaire first with their eyes open and then with their eyes shut. The Cronbach's alpha for this sample was .96. Campos et al. (2002) obtained a Cronbach's alpha of .88. Pérez-Fabello and Campos (2004) found that the Vividness of Visual Imagery Questionnaire correlated from -.40 to -.24 with the Gordon Test of Visual Imagery Control (Gordon test; Richardson, 1969). In a recent study, Pérez-Fabello and Campos (2020) obtained a Cronbach's alpha of .93 .

The Spanish version (Pérez-Fabello, \& Campos, 2004) of the Gordon Test of Visual Imagery Control (Gordon Test, Richardson, 1969) is comprised of 12 items in which participants are asked to imagine a motor car and then asked to rate on a 3 -point scale $(0=$ no, $1=$ unsure, 2 =yes) whether they can imagine it in various different colours, positions, and states of motion, for example "Can you see a car standing in the road in front of a house?" Total scores range from 0 to 24 , where high scores indicate better image-control. The Cronbach's alpha for this sample was .74. In studies previous, the Cronbach's coefficient of the Gordon Test was estimated at .69 (Pérez-Fabello \& Campos, 2004). Pérez-Fabello and Campos (2004) obtained a correlation of $-.40(p<.001)$ with the Vividness of Visual Imagery Questionnaire (VVIQ; Marks, 1973).

\section{Procedure}

The study was conducted in accordance with ethical rules contained in the Declaration of Helsinki of 2000, and was approved by the ethics committee of the University of the first author. All undergraduate students volunteered to participate in the study.

The translation process of the EIQ (Hausenblas et al., 1999) was performed in four steps. First, the first author, who is fluent in English and Spanish, translated the EIQ in Spanish. Then, the second author, who was also fluent in English and Spanish back-translated the EIQ back to English without referring to the original version. Third, the both authors drafted the final version of the EIQ. Finally, both authors and a professional English to Spanish translator, who is an expert in psychology, edited the syntax of the items, spelling, and any grammatical errors of the final version of the EIQ (see Appendix I).

At the gym of the Faculty of Physical Activity and Sports Sciences, the following questionnaires were administered in groups of approximately 20 participants: the EIQ, MIQ-R, VMIQ, VVIQ, and the Gordon Test. The order of tests was counterbalanced.

\section{Data Analysis}

Statistical analysis was performed using the IBM SPSS 20.0 software program and IBM SPSS Amos 20 (2011). In the preliminary analysis, atypical values on the scale were determined by the Mahalanobis distance. The baseline for defining a case as atypical was set at the very conservative level of .001, considering the indications of Hair, Anderson, Tatham, Black (1999). The univariate normality was assessed with the skewness and kurtosis where indexes close to zero and less than 2 indicate the 


\section{Spanish version of the EIQ}

similarity with the normal curve of univariate data (Bollen \& Long, 1993; Nuviala et al., 2012). Mardia's coefficient was used for multivariate normality. According to Bollen (1989), multivariaty normality exists when Mardia's coefficient is less than $p(p+2)$, where $\mathrm{p}$ is the number of variables observed.

To assess, if the hypothesis generated of the original studies was confirmed, we performed a confirmatory factor analysis (CFA) that gives model-fitting indicators (Jöreskog \& Sörbom, 1993, 1999). Global fit for models were assessed using six indexes: the $\chi 2$ to its degrees of freedom $(d f)$ ratio-because this index alone is very sensitive to sample size (Jöreskog \& Sörbom, 1993) - the goodness of fit index (GFI), the comparative fit index (CFI), the non-normed fit index (NNFI), the root mean square error of approximation (RMSEA), and the standardized root mean square residual (SRMR). Values of the $\chi 2$ to $d f$ ratio between 0 and 3 are recommended for a good fit (Bollen \& Long, 1993). GFI values higher than .90 are recommended, whereas values equal to .95 or higher are recommended for CFI and NNFI (Hu \& Bentler, 1999; Jöreskog \& Sörbom, 1993, 1999). Values equal to .08 or lower are recommended for RMSEA and SRMR (Browne \& Cudeck, 1993).

The Cronbach's alpha $(\alpha)$ and composite reliability (CR) were calculated to evaluate the internal consistency of the factors, and a cut-off value of .70 was applied as recommended by Nunnaly (1978) and Hair, Black, Babin, and Anderson (2014). As for convergent validity analysis (to confirm the items were related to their respective factor), the average variance extracted (AVE) was calculated using the recommended (AVE $\geq .50$ ) reference value (Hair et al., 2014). In relation to discriminant validity (to determine the factors were not related to each other are), the square of the factors correlations were confirmed to be below the AVE of the same (Hair et al., 2014). As a measure of concurrent criterion validity, the Pearson product-moment correlation coefficient was used to correlate the EIQ to the other imagery tests of comparable measures. Finally, the percentiles of the EIQ Subscales in both models (2factor and the 3-factor EIQ) are shown.

\section{RESULTS}

In the preliminary study, values of .001 were found during the calculation of the Mahalanobis distance, and in accordance with the conservative criterion of Hair et al. (1999), a baseline value of .001 was established for defining cases as outlier, with the removal of 11 observations.

As for univariate normality, the skewness and kurtosis indexes of the questionnaires were near zero and below the value of 2 . In addition, the univariate normality was calculated by the skewness and kurtosis of each item on the EIQ, obtaining values that in most items were close to zero or less than the 2 , which was above the recommended values (Bollen \& Long, 1993; Nuviala et al., 2012). Multivariate normality was confirmed by Mardia's coefficient 17.26 for the threefactor version, and 6.51 for the two-factor version of the EIQ (Bollen, 1989). The data normality obtained justified the use of the maximum likelihood method.

Figure 1 shows standardized coefficients for the proposed model, with values ranging from .55 (Item 2) to .94 (Item 8). All values were statistically significant $(p<.001)$. As estimated by the model, the relations among the three factors were .29 between technique and energy, .43 between energy and appearance, and .44 between technique and appearance.

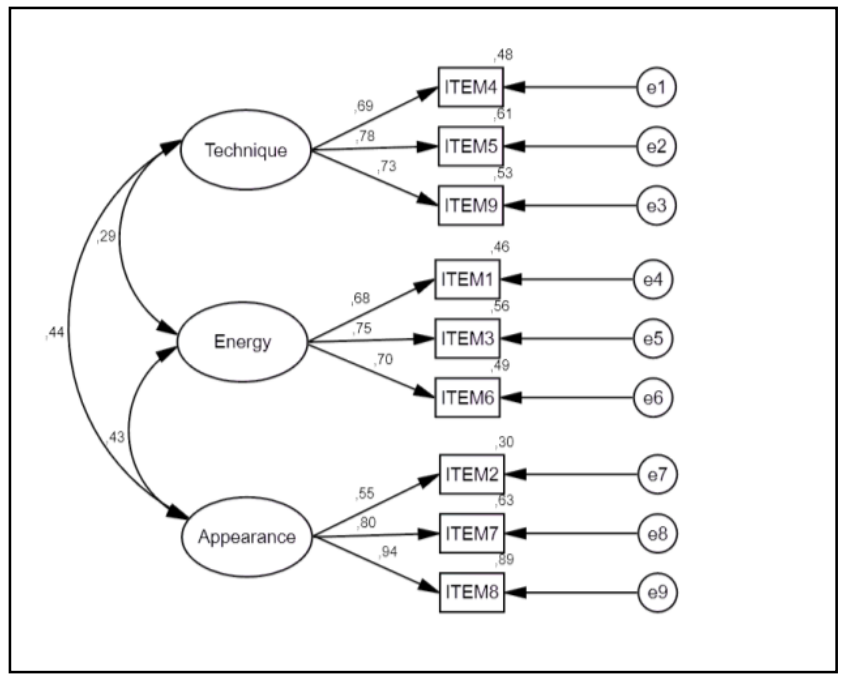

Figure 1. Three-factor model of Exercise Imagery Questionnaire (EIQ)

The initial model did not adjust satisfactorily to the data $\chi^{2}$ (68.65) and $d f(24)$, and the ratio was 2.86 ( $p$ $<.001)$. As the result of a Chi-square is particularly sensitive to sample size, it is usually accompanied by the ratio between the value and the degrees of freedom. This result was between 0 to 3 that can be considered a good model fit to data (Jöreskog \& 


\section{Pérez-Fabello, María José \& Campos, Alfredo}

Sörbom, 1993, 1999). The other Index values were: GFI (.91), CFI (.90), and NNFI (.86). The RMSEA and SRMR values were .11 and .08 . Though the data in the present study failed to reach the recommended values above .95 for CFI and NNFI (Hu \& Bentler, 1999; Jöreskog \& Sörbom, 1993, 1999), the GFI obtained a value higher than the recommended $.90(\mathrm{Hu} \&$ Bentler, 1999; Jöreskog \& Sörbom, 1993, 1999). Whilst the SRMR was within recommended values, the RMSEA failed to fulfil the recommendations of Browne and Cudeck (1993) as it exceeded the recommended value of .08 or lower for RMSEA and SRMR. As item 2 explained only $30 \%$ of the latent factor, and considering each dimension had 3 items, a model without the appearance factor was assessed with a short two-factor version of the EIQ for model improvement.

Figure 2 shows standardized coefficients for the proposed model, with values ranging from .65 (Item 1) to .81 (Item 5). All values were statistically significant $(p<.001)$. As estimated by the model, the relation between both factors was .43 between technique and energy.

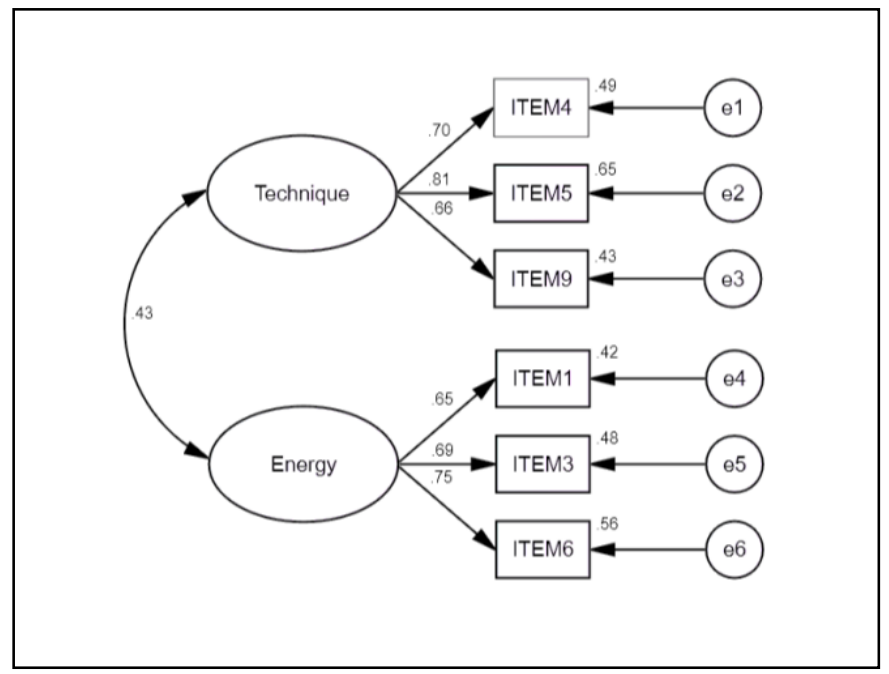

Figure 2. Two-factor model of Exercise Imagery Questionnaire (EIQ).

These values suggested a good fit for the model $\chi^{2}$ $(14.95)$ and $d f(8)$, ratio was $1.87(\mathrm{p}=.06)$. Index values were: GFI (.97), CFI (.97), and NNFI (.94). The RMSEA and SRMR values were .07 and .04 .

Internal consistency as measured by the Cronbach's alpha, and composite reliability are shown in Table 1. Most of the Cronbach's alphas were above .70 as suggested by Nunnaly (1978), and Hair et al. (2014).
However, composite reliability was below recommended values.

Table 1

Cronbach's Alpha, Composite Reliability of the three-Factor EIQ, and two-Factor EIQ

\begin{tabular}{lllll}
\hline $\begin{array}{l}\text { EIQ three } \\
\text { factors }\end{array}$ & $\begin{array}{l}\text { EIQtechniqu } \\
\mathrm{e}\end{array}$ & $\begin{array}{l}\text { EIQenerg } \\
\mathrm{y}\end{array}$ & $\begin{array}{l}\text { EIQappearanc } \\
\mathrm{e}\end{array}$ & $\begin{array}{l}\text { EIQtota } \\
1\end{array}$ \\
\hline $\begin{array}{l}\text { Cronbach' } \\
\text { s alpha }\end{array}$ & .78 & .75 & .78 & .78 \\
$\begin{array}{l}\text { Composite } \\
\text { Reliability }\end{array}$ & .64 & .34 & .59 & .73 \\
CR) & & & & \\
\hline $\begin{array}{l}\text { EIQ two } \\
\text { factors }\end{array}$ & & & \\
\hline $\begin{array}{l}\text { Cronbach' } \\
\text { s alpha }\end{array}$ & & & \\
$\begin{array}{l}\text { Composite } \\
\text { Reliability }\end{array}$ & .41 & .30 & & .70 \\
(CR) & & & & \\
\hline
\end{tabular}

The analysis of convergent validity evaluated several criteria. First, all of the standardized factorial loads were above .6, except for item 2 of the three-factor model. The $t$ values in both of the EIQ models proposed were above 1.96 , confirming the validity of the indicators used for measuring the constructs. Second, the results indicated that all the factors reached the recommended cut-off values (AVE $\geq .50$ ) (Hair et al., 2014). The discriminant validity of both of the models proposed showed the AVE value (figures in bold) for each factor were higher than the square of the correlation between the construct and each of the others (Hair et al., 2014) (see Table 2).

Table 2

Convergent and Discriminant Validity of the three-Factor EIQ, and twoFactor EIQ

\begin{tabular}{llll}
\hline $\begin{array}{l}\text { EIQ three } \\
\text { factors }\end{array}$ & EIQtechnique & EIQenergy & EIQappearance \\
\hline EIQtechnique & $\mathbf{. 5 4}$ & & \\
EIQenergy & .08 & $\mathbf{. 5 0}$ & \\
EIQappearance & .19 & .18 & $\mathbf{. 8 0}$ \\
\hline $\begin{array}{l}\text { EIQ two } \\
\text { factors }\end{array}$ & & & \\
\hline EIQtechnique & $\mathbf{. 5 3}$ & & \\
EIQenergy & .18 & $\mathbf{. 5 0}$ & \\
\hline
\end{tabular}

$\mathrm{AVE}=$ numbers in bold

Among the correlations between the EIQ scales and the other imagery tests, it is worth noting the correlation between the EIQ technique and the Gordon Test $(.26, p<.01)$. The EIQ energy subscale also correlated significantly -.16 with the visual MIQR ( $p$ $<.05)$, but the correlation was small as shown in see Table 3. The percentiles are included in Table 4. 


\section{Spanish version of the EIQ}

Table 3

Pearson Correlations between the Questionnaires and the EIQ Subscales

\begin{tabular}{|c|c|c|c|c|c|c|c|c|c|}
\hline Questionnaires & 1 & 2 & 3 & 4 & 5 & 6 & 7 & 8 & 9 \\
\hline $\begin{array}{l}1 \\
\text { VVIQ }\end{array}$ & & & & & & & & & \\
\hline $\begin{array}{l}2 \\
\text { Control Test }\end{array}$ & $-.34 *$ & & & & & & & & \\
\hline $\begin{array}{l}3 \\
\text { VMIQ }\end{array}$ & $.37 \%$ & $-.13 * *$ & & & & & & & \\
\hline $\begin{array}{l}4 \\
\text { MIQRvisual }\end{array}$ & $-.19 *$ & .03 & $-.29 \cdots$ & & & & & & \\
\hline $\begin{array}{l}5 \\
\text { MIQRkinesthetic }\end{array}$ & $-.31 * *$ & .08 & -.16 & $.51 \%$ & & & & & \\
\hline $\begin{array}{l}6 \\
\text { MIQRtotal }\end{array}$ & $-.30 *$ & .07 & $-.24 \cdots$ & $.81 *$ & $.92 *$ & & & & \\
\hline $\begin{array}{l}7 \\
\text { EIQtechnique }\end{array}$ & -.11 & $.26 * *$ & -.10 & .15 & .13 & .16 & & & \\
\hline $\begin{array}{l}8 \\
\text { EIQenergy }\end{array}$ & .03 & .06 & -.08 & -.16 & .02 & .06 & $.21{ }^{\circ *}$ & & \\
\hline $\begin{array}{l}9 \\
\text { EIQappearance }\end{array}$ & .05 & -.03 & -.06 & -.04 & .07 & .03 & $.42 *$ & $.36 *$ & \\
\hline $\begin{array}{l}10 \\
\text { EIQtotal }\end{array}$ & .06 & .13 & -.10 & -.05 & .09 & .04 & $.80 *$ & $.65 *$ & $.77 * *$ \\
\hline
\end{tabular}

Table 4

Percentiles, Standard Scores, and Direct Scores of the EIQ Subscales and the two-factor EIQtotal, and the three-factor EIQtotal

\begin{tabular}{|c|c|c|c|c|c|c|c|c|c|c|}
\hline \multirow[b]{2}{*}{$P$} & \multicolumn{2}{|c|}{ EIQtechnique } & \multicolumn{2}{|c|}{ EIQenergy } & \multicolumn{2}{|c|}{ EIQappearance } & \multicolumn{2}{|c|}{$\begin{array}{l}\text { EIQtotal } \\
\text { (2-factor) }\end{array}$} & \multicolumn{2}{|c|}{$\begin{array}{l}\text { EIQtotal } \\
\text { (3-factor) }\end{array}$} \\
\hline & $Z$ & $D S$ & $Z$ & $D S$ & $Z$ & $D S$ & $Z$ & $D S$ & $Z$ & $D S$ \\
\hline 5 & -1.81 & 13 & -1.69 & 5 & -1.74 & 12.5 & -1.54 & 24 & -1.52 & 41.5 \\
\hline 10 & -1.11 & 16 & -1.19 & 8 & -1.20 & 15 & -1.16 & 27 & -1.28 & 44 \\
\hline 20 & -.65 & 18 & -.70 & 11 & -.77 & 17 & -.78 & 30 & -.71 & 50 \\
\hline 30 & -.42 & 19 & -.38 & 13 & -.34 & 19 & -.40 & 33 & -.42 & 53 \\
\hline 40 & .05 & 21 & -.05 & 15 & .09 & 21 & -.15 & 35 & -.14 & 56 \\
\hline 50 & .28 & 22 & .28 & 17 & .31 & 22 & .10 & 37 & .24 & 60 \\
\hline 60 & .51 & 23 & .44 & 18 & .53 & 23 & .48 & 40 & .43 & 62 \\
\hline 70 & .74 & 24 & .77 & 20 & .745 & 24 & .73 & 42 & .82 & 66 \\
\hline 80 & .97 & 25 & .09 & 22 & .96 & 25 & 1.23 & 46 & 1.10 & 69 \\
\hline 90 & 1.44 & 27 & 1.42 & 24 & 1.40 & 27 & 1.49 & 48 & 1.48 & 73 \\
\hline
\end{tabular}

$P=$ Percentiles, $Z=$ Standard scores, $D S=$ Direct scores

\section{DISCUSSION}

The primary aim of this study was to validate the Spanish version of the Exercise Imagery Questionnaire (EIQ, Hausenblas et al., 1999) in a sample of Spanish undergraduates on the Bachelor's degree in Physical Activity and Sports Sciences, the results revealed the initial model, similar to the original study (3-factor / 9 items), failed to satisfactorily adjust to the data. However, as previously mentioned above, the model was adjusted by eliminating the factor appearance (with three items), and the new two-factor model was adequate.

The Cronbach's alphas of the two proposed EIQ models were acceptable, above .70. However, composite reliability was weak, not reaching the above .70 criterion (Hair et al., 2014), but most of these scores came close to .50 , considered by Hernández Mendo, Morales Sánchez and Triguero Molido (2013) as a reliable construct indices. The AVE in most cases was higher than the .50 , above the recommended value (Hair et al., 2014), indicating the construct explained more than half of the variance of all of its own indicators. In relation to discriminant validity, the results indicated the constructs were sufficiently independent among each other, given that in each factor the square of the factors correlations was below the AVE of the same (Hair et al., 2014).

Our results substantiated a three-factor model, similar to the model of the original study (Hausenblas et. al., 1999), and an improved adjusted two-factor model given that the three-factor model should be improved. A possible explanation for the discrepancies between the results of model in the present study and the model of the study original may by the difference in the sample populations under study. Hansenblas et al.'s (1999) study analysed two samples, $89 \%$ and $97.6 \%$, respectively, of women aerobic practitioners, in comparison to the present study with $77 \%$ male undergraduates of the Bachelor of Physical Activity and Sports Sciences degree who regularly practised an array of sports. Hall (1995) asserted mental imagery was related to the type of exercise, and may even be related to excessive exercise behaviour such as exercise dependence. Moreover, experience (the length of time one has been exercising) may also impact the functions of imagery (Munroe-Chandler \& Gammage, 2005).

The scores of the Spanish version of the EIQ scales were similar to those previously obtained by Gammage et al. (2004), who found significant correlations $(p<.01)$ among the three EIQ scales: technique imagery .52 with appearance imagery and .56 with energy imagery; and energy imagery .48 with appearance imagery. Besides, Gammage et al., (2004) obtained significant correlations between the EIQ scales and other scales related to exercise. Technique imagery correlated $.21(p<.01)$ with the Self-Presentation in Exercise Questionnaire (SPEQ, 


\section{Pérez-Fabello, María José \& Campos, Alfredo}

Conroy, Motl, \& Hall, 2000), and the SelfPresentational Efficacy Expectancy aspect of the SelfPresentational Efficacy Scale (SPES, Gammage et al., 2004), as well as .20 ( $p<.01)$ with the SelfPresentational Outcome Value aspect of the SPES. Energy imagery correlated $.15(p<.05)$ with the SelfPresentational Efficacy Expectancy aspect of the SelfPresentational Efficacy Scale (SPES). Lastly, appearance imagery was correlated $.33(p<.01)$ with the Social Physique Anxiety Scale (SPAS, Martin, Rejeski, Leary, McAuley, \& Bane, 1997); .27 ( $p<.01)$ with the SPEQ; and $.15(p<.01)$ with the SelfPresentational Outcome Value aspect of the SPES. However, we have only found a low correlation, although significant, between the EIQ technique and the the Gordon Test. It must be noted that the tests used by Gammage et al. (2004) were related to exercise. It may be the case that the various tests employed are measuring different types of images. This fact seems to indicate that image content plays an important role in image validity. Individuals may have very vivid images in a certain field but not in another, that is, they may easily visualise a specific exercise, but conversely have a hard time imagining a sunrise, a friend's face or a physical activity they have never practised. The EIQ refers to the frequency of use of common images during exercise in contrast to the images included in the imagery tests proposed. On the other hand, certain specific content may affect the vividness of images, and therefore, it may be linked to work or study environments, as is the case of other competencies such as creativity: individuals may be highly creative in one field but not in another (see, Cho, 2017). Further research is required to corroborate these hypotheses.

As evidenced by several studies, the benefits of exercise imagery in the field of sports range from increasing or maintaining the levels of exercise and physical activity (Giacobbi, Hausenblas, Fallon, \& Hall, 2003), to improving subjective vitality, physical self-esteem, self-confidence, and self-efficacy (Gammage et al., 2000;). Furthermore, recent studies have confirmed the benefits of exercise imagery for exercise beginners (Ajibua \& Peculiar, 2016; Duncan, Hall, Wilson, \& Rodgers, 2012; Kosteli, Williams, \& Cumming, 2018). Exercise initiates may create exercises by means of images, and therefore a targeted imagery intervention is appropriate in this population (Duncan et al., 2012), as well as in elderly adults although their images would be somehow different (Kosteli et al, 2018). When individuals are skilled and feel confident in a particular activity, they mostly want to keep on doing it.

The most notable limitations of the present study were sample size, poor gender parity, and the specific characteristics of the sample under study, two samples of university undergraduates of the Bachelor's degree in Physical Activity and Sports Sciences of a specific age and characteristics.

Further research is required to assess the reliability and validity of these tests in different age groups and in a wider array of sample populations. Moreover, other functions of mental imagery should be considered that take into account the novice and expert experience, the type of physical activity, and gender. Understanding the type and frequency of imagery used by individuals will enable the assessment of their effects on exercise.

\section{CONCLUSIONS AND PRACTICAL APPLICATIONS}

Owing to the impact of mental imagery on different sports (Fortes et al., 2019; Fortes et al., 2020; Frank et al., 2014, 2016; Meier et al., 2020; Moreno-Fernández et al., 2019; Peris-Delcampo, 2019; Rekik et al., 2019), the authors advocate, like Ajibua and Peculiar (2016), that coaches and trainers should use exercise imagery as a tool for fostering physical activity. Overall, mental exercise imagery invites further investigation with different measurement methods, including IEQ, which is considered a valid and useful test for exploring two kinds of imagery in particular: technique and energy.

\section{REFERENCES}

1. Ajibua, M. A., \& Peculiar, M. (2016). The relationship between exercise imagery and exercise self-Efficacy among University of Ibadan students. International Journal of Independent Research Studies, 3, 14-21. doi: 10.20448/800.3.1.14.21

2. Bollen, K. A. (1989). Structural equations with latent variables. New York: John Wiley and Sons.

3. Bollen, K. A., \& Long, J. S. (1993). Testing structural equation models. Newbury Park, CA: Sage. 


\section{Spanish version of the EIQ}

4. Browne, M. W., \& Cudeck, R. (1993). Alternative ways of assessing model fit. In K. A. Bollen \& J. S. Long (Eds.). Testing structural equation models (pp. 136-162). Newbury Park, CA: Sage.

5. Campos, A., López-Araujo, Y., \& Pérez-Fabello, M. J. (2016). Imágenes mentales utilizadas en diferentes actividades físicas y deportivas. Cuadernos de Psicología del Deporte, 16, 45-50.

6. Campos, A., \& González, M. A. (2010). Versión española del Cuestionario-Revisado de Imagen del Movimiento (MIQ-R): Validación y propiedades psicométricas [Spanish version of the Questionnaire-Revised image of the movement (MIQ-R): Validation and psychometric properties]. Revista de Psicología del Deporte, 19, 265-267.

7. Campos, A., González, M. A., \& Amor, A. (2002). The Spanish version of the Vividness of Visual Imagery Questionnaire: Factor structure and internal consistency reliability. Psychological Reports, $\quad 90, \quad 503-506 . \quad$ doi: 10.2466/pr0.2002.90.2.503

8. Campos, A., \& Pérez, M. J. (1990). A factor analytic study of two measures of mental imagery. Perceptual and Motor Skills, 71, 995-1001. doi: 10.2466/PMS.71.7.995-1001

9. Cho, J. Y. (2017). An investigation of design studio performance in relation to creativity, spatial ability, and visual cognitive style. Thinking Skills and Creativity, 23, 67-78. doi: 10.1016/j.tsc.2016.11.006

10. Conroy, D. E., Motl, R. W., \& Hall, E. G. (2000). Progress toward construct validation of the Selfpresentation in Exercise Questionnaire (SPEQ). Journal of Sport and Exercise Psychology, 22, 2138. doi: 10.1123/jsep.22.1.21

11. Cumming, J., \& Ramsey, R. (2009). Imagery interventions in sport. In S. D. Mellalieu \& S. Hanton (Eds.), Advances in applied sport psychology: A review (pp. 5-36). London: Routledge

12. Cumming, J., \& Williams, S. E. (2012). The role of imagery in performance. In S. Murphy (Ed.), Handbook of Sport and Performance Psychology (pp. 213-232). New York, NY: Oxford University Press
13. Decety, J. (1996). Neural representations for action. Reviews in the Neurosciences, 7, 285-297. doi: 10.1515/revneuro.1996.7.4.285

14. Di Rienzo, F., Debarnot, U., Daligault, S., Saruco, E., Delpuech, C., Doyon, J., et al. (2016).Online and offline performance gains following motor imagery practice: A comprehensive review of behavioral and neuroimaging studies. Frontiers in Human Neuroscience, 10:315. doi: 10.3389/fnhum.2016.00315

15. Duncan, L. R., Hall, C. R., Wilson, P. M., \& Rodgers, W. M. (2012). The use of a mental imagery intervention to enhance integrated regulation for exercise among women commencing an exercise program. Motivation and Emotion, 36, 452-464. doi: 10.1007/s11031-0119271-4

16. Frank, C., Land, W. M., Popp, C., \& Schack, T. (2014). Mental representation and mental practice: Experimental investigation on the functional links between motor memory and motor imagery. PLoS ONE 9:e95175. doi: 10.1371/journal.pone.0095175

17. Frank, C., Land, W. M., \& Schack, T. (2016). Perceptual-cognitive changes during motor learning: the influence of mental and physical practice on mental representation, gaze behavior, and performance of a complex action. Frontiers in Psychology. 6:1981. doi: 10.3389/fpsyg.2015.01981

18. Fortes, L. S., Almeida, S. S., Nascemento-Júnior, A. J. R., Fiorese, L., Lima-Júnior, D., \& Caputo Ferreira, M. E. (2019). Effect of motor imagery training on tennis service performance in young tennis athletes. Revista de Psicología del Deporte, $28,157-168$.

19. Fortes, L. S., Freitas-Júnior, C. G., Paes, P. P., Vieira, L. F., Nascimento-Júnior, J. R. A., LimaJúnior, D. R. A. A., \& Ferreira, M. E. C. (2020). Effect of an eight-week imagery training programme on passing decision-making of young volleyball players. International Journal of Sport and Exercise Psychology, 18, 120-128. doi: 10.1080/1612197X.2018.1462229

20. Gammage, K. L., Hall, C. R., \& Ginis, K. A. M. (2004). Self-presentation in exercise contexts: Differences between high and low frequency 


\section{Pérez-Fabello, María José \& Campos, Alfredo}

exercisers. Journal of Applied Social Psychology, 34 , 1638-1651. doi: 10.1111/j.15591816.2004.tb02791.x

21. Gammage, K. L., Hall, C. R., \& Rodgers, W. M. (2000). More about exercise imagery. The Sport Psychologist, $\quad 14, \quad 348-359$. doi/10.1123/tsp.14.4.348

22. Giacobbi, P. R., Jr., Hausenblas, H. A., Fallon, E. A., \& Hall, C. A. (2003). Even more about exercise imagery: A grounded theory of exercise imagery. Journal of Applied Sport Psychology, 15, 160-175. doi.org/10.1080/10413200305391

23. Giacobbi, P. R., Jr., Hausenblas, H. A., \& Penfreld, R. D. (2005). Further refinements in the measurement of exercise imagery: The exercise imagery inventory. Measurement in Physical Education and Exercise Science, 9, 251-266. doi: 10.1207/s15327841mpee0904_4

24. Hair, J. F., Anderson, R. E., Tatham R. L., \& Black, W. C. (1999). Multivariate data analysis. Upper Saddle River, NJ: Prentice-Hall International.

25. Hair, J.F., Black, W. C., Babin, B., \& Anderson, R. E. (2014). Multivariate data analysis (7 th ed.). Upper Saddle River, NJ: Pearson Educational.

26. Hall, C. R. (1995). The motivational function of mental imagery for participation in sport and exercise. In J. Annett, B. Cripps, \& H. Steinberg (Eds.), Exercise addiction: Motivation form participation in sport and exercise (pp. 15-21). Leicester, UK: British Psychological Society

27. Hall, C., \& Martin, K. A. (1997). Measuring movement imagery abilities: A revision of the Movement Imagery Questionnaire. Journal of Mental Imagery, 21, 143-154

28. Hall, C. R., Rodgers, W. M., Wilson, P. M., \& Norman, P. (2010). Imagery use and selfdetermined motivations in a community sample of exercisers and non-exercisers. Journal of Applied Social Psychology, 40, 135-152. doi:10.1111/j.1559-1816.2009.00566.x

29. Hausenblas, H. A., Hall, C. R., Rodgers, W. M., \& Munroe, K. J. (1999). Exercise imagery: Its nature and measurement. Journal of Applied Sport Psychology, $\quad 11, \quad$ 171-180. doi: 10.1080/10413209908404198
30. Hernández Mendo, A., Morales Sánchez, V. \& Triguero Florido, J. D. (2013). Propiedades psicométricas de un cuestionario para estudiar el flow contextual. Revista Iberoamericana de Psicología del Ejercicio y el Deporte, 8, 253-279.

31. Hu, L., \& Bentler, P. M. (1999). Cutoff criteria for fit indexes in covariance structure analysis. Conventional criteria versus new alternatives. Structural Equation Modeling, 6, 1-55. doi: 10.1080/10705519909540118

32. Isaac, A., Marks, D. F., \& Russell, D. G. (1986). An instrument for assessing imagery of movement: The Vividness of Movement Imagery Questionnaire. Journal of Mental Imagery, 10, 2330

33. Jöreskog, K. G., \& Sörbom, D. (1993). LISREL.8. Structural equation modeling with the SIMPLIS command language. Hillsdale, NJ: LEA.

34. Jöreskog, K. G., \& Sörbom, D. (1999). LISREL.8.User's reference guide. Lincolnwood, IL: Scientific Software International, Inc.

35. Kossert, A. L., \& Munroe-Chandler, K. (2007). Exercise imagery: A systematic review of the empirical literature. Journal of Imagery Research in Sport and Physical Activity, 2, 34. doi: 10.2202/1932-0191.1015

36. Kosteli, M. C., Williams, S. E., \& Cumming, J. (2018). Exploring imagery as a technique for promoting physical activity in older adults. Imagination, Cognition and Personality First Published April 5. doi: 10.1177/0276236618767083

37. Lebon, F., Ruffino, C., Greenhouse, I., Labruna, L., Ivry, R. B., \& Papaxanthis, C. (2019). The neural specificity of movement preparation during actual and imagined movements. Cerebral Cortex, 29, 689-700. doi: 10.1093/cercor/bhx350

38. Marks, D. F. (1973). Visual imagery differences in the recall of pictures. British Journal of Psychology, 64, 17-24. doi: 10.1111/j.20448295.1973.tb01322.x

39. Martin, K. A., Rejeski, W. J., Leary, M. R., McAuley, E., \& Bane, S. (1997). Is the Social Physique Anxiety Scale really multidimensional? Conceptual and statistical arguments for a unidimensional model. Journal of Sport and 


\section{Spanish version of the EIQ}

Exercise Psychology, 19, 359-367. doi: 10.1123/jsep.19.4.359

40. Meier, C., Frank, C., Gröben, B., and Schack, T. (2020). Verbal instructions and motor learning: How analogy and explicit instructions influence the development of mental representations and tennis serve performance. Frontiers in Psychology, 11:2. doi: 10.3389/fpsyg.2020.00002

41. Moran, A. \& O’Shea, H. (2020). Motor imagery practice and cognitive processes. Frontiers in Psychology, 11:394. doi: 10.3389/fpsyg.2020.00394

42. Moreno-Fernández, I., Gómez-Espejo, V., Belén Olmedilla-Caballero, B., Luis Miguel RamosPastranaL. M., Ortega-Toro, E., \& OlmedillaZafra, A. (2019). Eficacia de un programa de preparación psicológica en jugadores jóvenes de fútbol. Revista de Psicología Aplicada al Deporte y al Ejercicio Físico, 4, e14, 1-7. doi: 10.5093/rpaedf2019a13

43. Munroe-Chandler, K. J., \& Gammage, K. L. (2005). Now see this: A new vision of exercise imagery. Exercise and Sport Sciences Reviews, 33, 201-205. doi: 10.1097/00003677-20051000000009

44. Nunnally J. C. (1978). Psychometric theory. NewYork, NY: McGraw-Hill Inc.

45. Nuviala, A., Teva-Villén, M. R., Grao-Cruces, A., Pérez-Ordás, R., García-Fernández, J., \& Nuviala, R. (2012). Validity, reliability and exploratory factor analysis of the dropout scale in sport centres. Journal of Human Sport \& Exercise, 7, 275-286. doi: 10.4100/jhse.2012.71.06

46. Paivio, A. (1985). Cognitive and motivational functions of imagery in human performance. Canadian Journal of Applied Sport Sciences, 10, 22-28.

47. Palmi Guerrero, J, \& Riera Riera, J. (2016). Las competencias del deportista para el rendimiento. Cuardernos de Psicología del Deporte, 17, 13-18.

48. Pérez-Fabello, M. J., \& Campos, A. (2004). Factor structure and internal consistency of the Spanish version of the Gordon Test of Visual Imagery Control. Psychological Reports, 94, 761-766. doi: 10.2466/PR0.94.3.761-766
49. Pérez-Fabello, M. J. \& Campos, A. (2020). Spanish version of the Plymouth Sensory Imagery Questionnaire. Frontiers in Psychology, 11:916. doi: 10.3389/fpsyg.2020.00916

50. Pérez-Fabello, M. J., Campos, A., \& CamposJuanatey, D. (2016). Is object imagery central to artistic performance? Thinking Skills Creativity, 21, 67 -74. doi: 10.1016/j.tsc.2016.05.006

51. Peris-Delcampo, D. (2019). Intervención psicológica a distancia con un futbolista profesional: Estudio de caso. Revista de Psicología Aplicada al Deporte y al Ejercicio Físico, 4, e15, 1-8. doi: 10.5093/rpaedf2019a14

52. Rekik, G., Khacharem, A., Belkhir, Y., Bali, N., \& Jarraya, M. (2019). The effect of visualization format and content complexity on acquisition of tactical actions in basketball. Learning and Motivation, 65, 10-19. doi: 10.1016/j.lmot.2018.12.001

53. Richardson, A. (1969). Mental imagery. New York: Springer.

54. Rodgers, W. M., Hall, C. R., Blanchard, C. M., \& Munroe, K. J. (2001). Prediction of obligatory exercise by exercise-related imagery. Psychology of Addictive Behaviors, 15, 152-154. doi: 10.1037/0893-164X.15.2.152

55. Rodgers, W. M., Munroe, K. J., \& Hall, C. R. (2002). Relations among exercise imagery, selfefficacy, exercise behavior, and intentions. Imagination, Cognition and Personality, 21, 5565. doi: 10.2190/UV5C-0HK0-7NYP-235K

56. Simons, J. (2000). Doing imagery in the field. In M. B. Andersen (Eds.), Doing Sport Psychology (pp. 77-92). Champaign, IL: Human Kinetics

57. Stanley, D. M., Cumming, J., Standage, M., \& Duda, J. L. (2012). Images of exercising: Exploring the links between exercise imagery use, autonomous and controlled motivation to exercise, and exercise intention and behavior. Psychology of Sport and Exercise, 13, 133-141. doi: 10.1016/j.psychsport.2011.10.002

58. Vadocz, E. A., Hall, C. R. \& Moritz, S. E. (1997). The relationship between competitive anxiety and imagery use. Journal of Applied Sport Psychology, 9, 141-153. doi: 10.1080/10413209708406485 


\section{Pérez-Fabello, María José \& Campos, Alfredo}

59. Wilson, P. M., Rodgers, W. M., Hall, C. R., \& Gammage, K. L. (2003). Do autonomous exercise regulations underpin different types of exercise imagery? Journal of Applied Sport Psychology, 15, 294-306. doi: 10.1080/714044198

60. Zabicki, A., de Haas, B., Zentgraf, K., Stark, R., Munzert, J., \& Krüger, B. (2019). Subjective vividness of motor imagery has a neural signature in human premotor and parietal cortex. NeuroImage 197, 273-283. doi: 10.1016/j.neuroimage.2019.04.073

\section{Appendix I}

Exercise Imagey Questionnaire (EIQ)

Cuestionario de Imagen del Ejercicio (EIQ)

Instrucciones. La imagen implica verse uno a sí mismo haciendo ejercicio. La imagen que tienes en tu mente debería aproximarse a la actividad física real, tanto como sea posible. La imagen puede incluir las sensaciones y sentimientos que tienes cuando haces los movimientos del ejercicio.

Tu tarea consiste en cubrir este cuestionario indicando la frecuencia con la que tienes las imágenes que te describen. Si la imagen se repite siempre, puntúas con un 9 , y si no se produce nunca, puntúa con un 1. Las frecuencias intermedias también llevan puntuaciones intermedias.

En todo el test hay que hacer referencia a las puntuaciones de la escala cuando juzgues la frecuencia de cada imagen. Cuando cubras un ítem, no te fijes en los ítems que ya has cubierto antes. Trata de hacer cada ítem separada e independientemente de cómo hayas podido hacer otros ítems. Lo importante es tu valoración sincera.

Si no tienes ninguna pregunta, puedes comenzar.

\section{Puntuaciones de la Escala Puntuación}

Siempre.......................... 9

Casi siempre....................... 8

Muy frecuentemente.............. 7

Frecuentemente.................. 6

Ocasionalmente.................. 5
Raramente...................... 4

Muy raramente.................... 3

Casi nunca....................... 2

Nunca......................... 1

Items

1. Para mantenerme en forma durante el día, me imagino haciendo ejercicio.

(To keep me going during the day, I imagine exercising).

2. Me imagino "más en forma" haciendo ejercicio.

(I imagine a "fitter-me" from exercising).

3. Para evadir mi mente de mi trabajo, me imagino haciendo ejercicio.

(To take my mind off my work, I imagine exercising).

4. Cuando pienso en hacer ejercicio, me imagino perfeccionando mi técnica.

(When I think about exercising, I imagine perfecting my technique).

5. Cuando pienso en hacer ejercicio, me imagino la forma y la posición de mi cuerpo.

(When I think about exercising, I imagine my form and body position).

6. Me imagino haciendo ejercicio para sentirme lleno de energía.

(To get me energized, I imagine exercising).

7. Me imagino "más ágil" haciendo ejercicio.

(I imagine a "leaner-me" from exercising).

8. Me imagino "más fuerte" haciendo ejercicio.

(I imagine a "firmer-me" from exercising).

9. Cuando pienso en hacer ejercicio, me imagino haciendo los movimientos necesarios.

(When I think about exercising, I imagine doing the required movements). 